\title{
Gemcitabine/Cisplatin Treatment Induces Concomitant SERTAD1, CDKN2B and GADD45A Modulation and Cellular Changes in Bladder Cancer Cells Regardless of the Site of TP53 Mutation
}

\author{
Glenda Nicioli da Silva ${ }^{1,2}$ - Leandro Toshio Filoni ${ }^{3}$ - Maria Cecília Salvadori ${ }^{3}$. \\ Daisy Maria Fávero Salvadori ${ }^{4}$
}

Received: 25 November 2016 / Accepted: 23 May 2017 / Published online: 2 June 2017

(C) Arányi Lajos Foundation 2017

\begin{abstract}
Simultaneous use of cisplatin (CIS) and gemcitabine (GEN) for treating bladder cancer has increased because of their complementary effects. However, the molecular mechanisms underlying the activities of these two antineoplastic drugs are not fully known. Here, molecular biology techniques and microscopy were used to investigate transcriptomic and morphological changes in low and highgrade urinary bladder transitional carcinoma cell lines [RT4 wild type TP53; 5637 - two TP53 mutations, one in codon 72 (Arg-Pro) and other in codon 280 (Arg-Thr) and T24 - inframe deletion of tyrosine 126 in the TP53 allele] simultaneously treated with CIS/GEN. Gene expression profile was evaluated by PCR arrays; cell morphology by scanning and transmission electron microscopy, and apoptosis was analyzed using fluorescent dye. Results showed concomitantly upregulation of $C D K N 2 B$ (G1/S transition), GADD45A (DNA repair and apoptosis) and SERTAD1 (regulation of transcription) gene, increased number of nuclear chamfers and apoptotic cells, and reduced number of microfilaments, organelles and in the size of the nucleus in 5637 and T24 cells after
\end{abstract}

Glenda Nicioli da Silva

nicioli@ef.ufop.br

1 School of Pharmacy, UFOP - Federal University of Ouro Preto, Ouro Preto, MG, Brazil

2 Escola de Farmácia, Departamento de Análises Clínicas, UFOP Universidade Federal de Ouro Preto, Ouro Preto, MG 35400-000, Brazil

3 Institute of Physics, USP - University of São Paulo, São Paulo, SP, Brazil

4 Medical School, UNESP - State University of São Paulo, Botucatu, SP, Brazil simultaneous treatment with CIS/GEN. In conclusion, independently of the TP53 mutation status and tumor grade, CIS/ GEN induced gene modulation accompanied by changes in cell morphologies, which confirm the antiproliferative activity of the treatment protocol. These findings help to understand the pathways modulated by these antineoplastic agents and may provide insights for anti-cancer chemotherapy.

Keywords Bladder cancer · Cell morphology ·

Chemotherapy $\cdot$ Cisplatin $\cdot$ Gene expression $\cdot$ Gemcitabine

\section{Introduction}

Several antineoplastic protocols have been extensively evaluated with the aim of improving patient survival and quality of life. A phase III trial of bladder cancer tumors indicated the methotrexate, vinblastine, adriamycin and cisplatin (MVAC) chemotherapy has an efficacy that was similar to that of a 2drug regimen that included cisplatin and gemcitabine [1]. More recently, Yuh et al. [2] confirmed that neoadjuvant treatment with cisplatin and gemcitabine may warrant further prospective assessment. The mechanisms of action of cisplatin and gemcitabine are different. Cisplatin induces DNA crosslinking and causes severe lesions that can lead to apoptosis [3]. However, gemcitabine is a deoxycytidine analog that forms an active dFdCTP metabolite when phosphorylated. It is then incorporated into DNA, where it blocks replication [4].

Transcriptome studies performed over the last decade have helped us to identify molecular mechanisms that are related to tumorigenesis in different organs and to promote a more comprehensive understanding of chemotherapeutic protocols [5]. The characterization of genes known to facilitate tumor sensitivity to different antineoplastic drugs has played a key role 
in selecting the most optimal therapeutic strategies [6]. Using a PCR array, da Silva et al. [7] showed that in vitro treatment with only gemcitabine modulated several molecular pathways, including DNA repair, G1/S transition, apoptosis and transcription factors, in bladder tumor cell lines. Furthermore, Sávio et al. [8] used RT-qPCR to demonstrate that allyl isothiocyanate (AITC), an abundant compound that is found in cruciferous vegetables and mustard seeds, possesses promising antineoplastic potential. These authors showed that AITC had an important effect on the $B A X / B C L 2$ axis in wild-type TP53 bladder tumor cells and on ANLN and S100P gene expression in a TP53-mutated cell line. These data suggested that AITC might induce cell cycle arrest. In addition to gene expression profiling, morphological data are also important for establishing diagnoses and indicating prognoses while treating a patient for cancer. Changes in cell morphology and growth that were characteristic of neoplastic development were detected in Vero cells that were treated with cisplatin [9]. Moreover, morphological changes, including rounding and shrinkage in a glioma cell line (GBM-8401), were visualized after 24 and $48 \mathrm{~h}$ of incubation with AITC, suggesting that this agent is an effective treatment option [10].

The present study was designed to answer the need to identify biomarkers that can be used to anticipate the effectiveness of antineoplastic treatments. Because combined treatment with gemcitabine/cisplatin has been supported as a promising chemotherapeutic protocol for bladder cancer and because TP53 mutations are among the most frequent gene modifications observed in bladder cancer cells [11], the aim of this study was to investigate the effect of administering these two drugs in combination on cell cycle-related gene expression and cell morphology in bladder tumor cell lines with two different TP53 mutation statuses. PCR-arrays and transmission and scanning electron microscopy were used.

\section{Material and Methods}

\section{Cell Lines and Test Compounds}

The established cell lines RT4, 5637 and T24, which were obtained from human bladder urothelial cell carcinomas (UCCs), were purchased from the Cell Bank of the Federal University of Rio de Janeiro, Brazil. The RT4 cell line (wild type TP53) is derived from a low grade papillary bladder tumor. Lineage 5637 harbors two TP53 mutations, one in codon 72 (Arg-Pro) and other in codon 280 (Arg-Thr). The T24 cell line, which was obtained from an invasive tumor, encodes an in-frame deletion of tyrosine 126 in the TP53 allele. The cells were maintained as previously described by Da Silva et al. [12] and recently tested for contamination.

The antineoplastic drugs that were used include gemcitabine (dFdC, Gemzar), which was obtained from Eli
Lilly Laboratory (Eli Lilly and Company, USA), and cisplatin (CDDP), which was obtained from Sigma-Aldrich USA). Ultra-pure sterilized water was used for all dilutions.

\section{Experimental Design}

The cells were seeded into 12 -well culture plates at $1.5 \times 10^{4}$ cells per plate. After $24 \mathrm{~h}$, the cultures were treated with cisplatin $(0.5,1.0,2.5$, or $5.0 \mu \mathrm{mol} / \mathrm{L})$, gemcitabine $(0.78,1.56$, 3.12 , or $6.25 \mu \mathrm{mol} / \mathrm{L}$ ) or both drugs simultaneously $(0.5 \mu \mathrm{mol} / \mathrm{L}$ cisplatin $+0.78 \mu \mathrm{mol} / \mathrm{L}$ gemcitabine, $0.5 \mu \mathrm{mol} /$ $\mathrm{L}$ cisplatin $+1.56 \mu \mathrm{mol} / \mathrm{L}$ gemcitabine, $1.0 \mu \mathrm{mol} / \mathrm{L}$ cisplatin $+0.78 \mu \mathrm{mol} / \mathrm{L}$ gemcitabine, or $1.0 \mu \mathrm{mol} / \mathrm{L}$ cisplatin $+1.56 \mu \mathrm{mol} / \mathrm{L}$ gemcitabine) and incubated for an additional $24 \mathrm{~h}$. These drug concentrations were chosen based on a protocol described in a previous study [12]. Untreated cells were cultured in parallel and used as the negative control. After $24 \mathrm{~h}$ of incubation with the drugs, the cells were washed with Hank's solution $\left(0.4 \mathrm{~g} \mathrm{KCl}, 0.06 \mathrm{~g} \mathrm{KH}_{2} \mathrm{PO} 4,0.04 \mathrm{~g}\right.$ $\mathrm{Na}_{2} \mathrm{HPO} 4,0.35 \mathrm{~g} \mathrm{NaHCO}_{3}, 1 \mathrm{~g}$ glucose and $8 \mathrm{~g} \mathrm{NaCl}$ in $1000 \mathrm{~mL} \mathrm{H}_{2} \mathrm{O}$ ), and complete fresh medium was then added. The cells were collected for apoptosis assays immediately after $24 \mathrm{~h}$ of treatment was completed (designated $0 \mathrm{~h}$ ) and at 24 and $48 \mathrm{~h}$ after treatment was ended. To analyze morphological alterations and gene expression profiles, cells were treated for $24 \mathrm{~h}$ with $1.56 \mu \mathrm{mol} / \mathrm{L}$ gemcitabine and $1.0 \mu \mathrm{mol} / \mathrm{L}$ cisplatin. As shown in comet assays and trypan blue and XTT tests, these two concentrations were genotoxic but not cytotoxic in the two cell lines that were used [13].

\section{Scanning Electron Microscopy}

Cells were seeded under normal conditions in 12-well culture plates and placed under coverslips. After the cells were treat with the drugs, they were washed four times with $0.5 \mathrm{M}$ sodium cacodylate buffer and fixed with $0.1 \%$ glutaraldehyde and $4 \%$ formaldehyde for $30 \mathrm{~min}$. Then, the cells were washed again with $0.5 \mathrm{M}$ cacodylate buffer, postfixed in $1 \%$ osmium tetroxide for $20 \mathrm{~min}$, dehydrated in a graded series of ethanol solutions, critical-point dried (Balzers CDT 030) and coated with gold for $60 \mathrm{~s}$ using a sputter coater (Balzers CDT 050). The samples were analyzed using a scanning electron microscope (JEOL JSM model 6460). These experiments were performed in triplicate.

\section{Transmission Electron Microscopy}

Cells were seeded under normal conditions in 12-well culture plates and placed under coverslips. The cells were then fixed with glutaraldehyde and washed with phosphate buffer three times. Osmium tetroxide (1\%) was added, and $2 \mathrm{~h}$ later, the cells were washed with distilled water. Aftare $2 \mathrm{~h}$ of incubation in $0.5 \%$ uranyl acetate, the cells were dehydrated in $50 \%, 70 \%$, $90 \%$ and then $100 \%$ acetone. Then, an Araldite ${ }^{\circledR}$ resin with 
acetone mixture was added, and the plates were incubated overnight. Pure resin was then added, and the plates were incubated at $37^{\circ} \mathrm{C}$ for 2 days. Ultra-thin sections were cut from the blocks containing the cells, and the blocks were stained with uranyl acetate and lead citrate. Then, the cells were analyzed using a Tecnai Spirit by Fei Company transmission electron microscope [14]. These experiments were performed in triplicate.

\section{Apoptosis Assay}

Three fluorescent dyes were used to evaluate the rates of apoptosis and necrosis in 5637 and T24 cells to check whether mutational site can influence the type of cell death: Hoechst 33,342 (stains DNA in viable cells), propidium iodide (identifies ruptured cell membranes) and fluorescein diacetate (indicates viable cells). After drug treatments, the cells were incubated with $10 \mu \mathrm{l}$ Hoechst 33,342 $(1 \mathrm{mg} / \mathrm{ml}), 25 \mu \mathrm{l}$ propidium iodide $(1 \mathrm{mg} / \mathrm{ml})$ and $50 \mu \mathrm{l}$ fluorescein diacetate $(1.5 \mathrm{mg} / \mathrm{ml})$ for $5 \mathrm{~min}$ at $37{ }^{\circ} \mathrm{C}$. Then, the cells were examined using a fluorescent microscope with a triple filter for DAPI, FITC and rhodamine. A total of 500 cells from three independent experiments were scored. The following criteria were adopted: 1) normal cells: blue intact nucleus and green cytoplasm; 2) apoptotic cells: blue nucleus with green cytoplasm and apoptotic bodies; 3) necrotic cells: red intact nucleus and cytoplasm.

\section{RNA Extration and PCR ARRAYS}

To evaluate changes in the gene expression profile in 5637 and T24 cell lines, gemcitabine and cisplatin were used at concentrations of $1.56 \mu \mathrm{mol} / \mathrm{L}$ and $1.0 \mu \mathrm{mol} / \mathrm{L}$, respectively.

Total RNA was extracted using RNeasy Mini kits (Qiagen) according to the manufacturer's instructions and stored at $-80{ }^{\circ} \mathrm{C}$. RNA integrity and quality were evaluated using $2 \%$ denaturing agarose gels and Nanovue equipment (Thermo Fischer), respectively. A cell cycle pathway PCR array (PAHS-020a - Human Cell Cycle PCR Array - 84 genes SA Biosciences) was used for the RT-qPCR analysis. RNA was reverse transcribed using an RT2 first strand kit (SA Biosciences) according to the manufacturer's instructions. An aliquot of the diluted first-strand synthesis reaction was added to Sybr Green/Rox Master Mix (SA Biosciences) and nucleasefree water, in accordance with the PCR array system's user manual. Then, $25 \mu \mathrm{l}$ of the cDNA/master mix cocktail was added to each well of the pathway-specific RTq-PCR microplate. The plate was sealed and transferred to the Real TimePCR equipment, where the cycling profile was performed as described by the manufacturer instructions. Data were analyzed using the method of $\Delta \Delta \mathrm{CT}$. In this case, the $\mathrm{Ct}$ values were calculated and melting curves were constructed. The quality controls used to evaluate genomic DNA contamination, reverse transcription efficiency and PCR amplification efficiency were then analyzed. The RT-qPCR array data were normalized using the arithmetic mean values of two reference genes (GAPDH and $A C T B$ ) for 5637 and T24 cell lines. All the arrays were performed in triplicate. Analyses of significant gene clusters were performed using bioinformatics tools available on page http:// pcrdataanalysis.sabiosciences.com/pcr/arrayanalysis.php. Information about the biological functions of the genes was obtained from FATIGO (http://babelomics.bioinfo.cipf.es/).

\section{Statistical Analysis}

One-way ANOVA was used to analyze the apoptosis data. The gene expression data were evaluated as fold changes. In this case, $p$ values were calculated using Student's t-test with triplicate values for each gene in the control and treatment groups. $p \leq 0.05$ was considered to indicate statistical significance.

\section{Results}

\section{Scanning Electron Microscopy}

After cells were treated according to each antineoplastic drug protocol, the reduction in the number of cells was determined in three cell lines (RT4, 5637 and T24). Figures 1, 2 and 3 show the irregular morphology and reduced number of microfilaments that were visualized in RT4, 5637 and T24 cells after treatment with gemcitabine or a combination of gemcitabine/ cisplatin. Characteristic apoptotic cells were observed in the 5637 cultures that were treated with $1.0 \mu \mathrm{mol} / \mathrm{L}$ cisplatin $+1.56 \mu \mathrm{mol} / \mathrm{L}$ gemcitabine (Fig. $2 \mathrm{D}$ ).

\section{Transmission Electron Microscopy}

Initially, an analysis using transmission electron microscopy showed that there were differences between the untreated (control) RT4, 5637 and T24 cells. T24 showed more cytoplasmic prolongations with irregular shapes, clearer nucleoli, different organelles (e.g., endoplasmic reticulum, mitochondria and Golgi apparatus) in the cytoplasm, electron-dense granules (probably protein-derived material) and larger nuclei than the RT4 and 5637 cells (Fig. 4). However, the three cell lines had similar morphological characteristics after treatment and showed a decrease in the size of the nucleus. Increases in the number and size of nuclear chamfers and a decreased number of organelles were observed mainly in TP53 mutated cells (Figs. 5 and 6).

\section{Apoptosis Assay}

A statistically significant increase in the frequency of cell death (via apoptosis and necrosis) was observed in the 5637 cultures that were treated with cisplatin and/or gemcitabine. The highest percentage of apoptotic cells was detected at $48 \mathrm{~h}$ after treatment $(15.86 \%$ for $5.0 \mu \mathrm{mol} / \mathrm{L}$ cisplatin and $16.6 \%$ 
Fig. 1 Photomicrographs of RT4 cells were obtained using scanning electron microscopy: (a) untreated (controls), (b) treated with cisplatin $(1.0 \mu \mathrm{mol} / \mathrm{L}),(\mathbf{c})$ treated with gemcitabine $(1.56 \mu \mathrm{mol} / \mathrm{L})$, or D) treated with cisplatin + gemcitabine $(1.0 \mu \mathrm{mol} / \mathrm{L}$ cisplatin $+1.56 \mu \mathrm{mol} / \mathrm{L}$ gemcitabine). Black arrows indicate microfilaments, and white arrows indicate irregular morphology Scale bar: $10 \mu \mathrm{m}$. These experiments were performed in triplicate

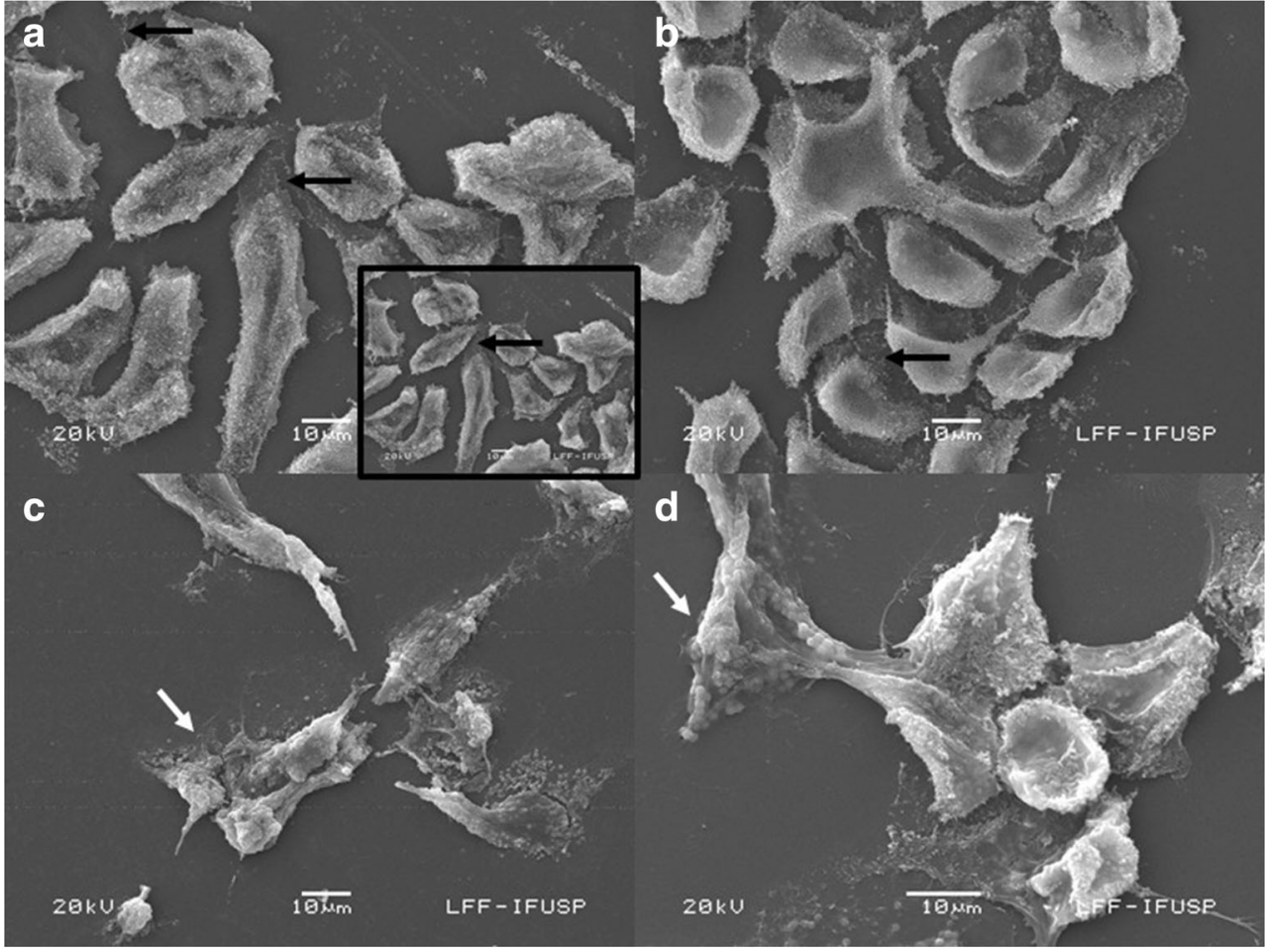

for $6.25 \mu \mathrm{mol} / \mathrm{L}$ gemcitabine). However, the highest percentage of necrotic cells was observed immediately after $(0 \mathrm{~h})$ treatment with cisplatin $(5.66 \%$ for $5.0 \mu \mathrm{mol} / \mathrm{L})$ or gemcitabine $(2.32 \%$ for $0.78 \mu \mathrm{mol} / \mathrm{L})$ and at $48 \mathrm{~h}$ after treatment with cisplatin + gemcitabine (19.8\%). However, treatment with a combination of these drugs increased the number of necrotic cells at the three timepoints that were tested (Table 1). In T24 cells, a significant increase was observed in the proportion of apoptotic cells after $24 \mathrm{~h}(3.20 \%$ for $3.125 \mu \mathrm{mol} / \mathrm{L}$ and $4.0 \%$ for $6.25 \mu \mathrm{mol} / \mathrm{L})$ and $48 \mathrm{~h}(3.60 \%$
Fig. 2 Photomicrographs of 5637 cells were obtained using scanning electron microscopy: (a) untreated (controls), (b) treated with cisplatin $(1.0 \mu \mathrm{mol} / \mathrm{L}),(\mathbf{c})$ treated with gemcitabine $(1.56 \mu \mathrm{mol} / \mathrm{L})$, or $(\mathbf{d})$ treated with cisplatin + gemcitabine

$(1.0 \mu \mathrm{mol} / \mathrm{L}$ cisplatin $+1.56 \mu \mathrm{mol} / \mathrm{L}$ gemcitabine). Black arrows indicate microfilaments, and white arrows indicate apoptotic cells. Scale bar: $10 \mu \mathrm{m}$. These experiments were performed in triplicate

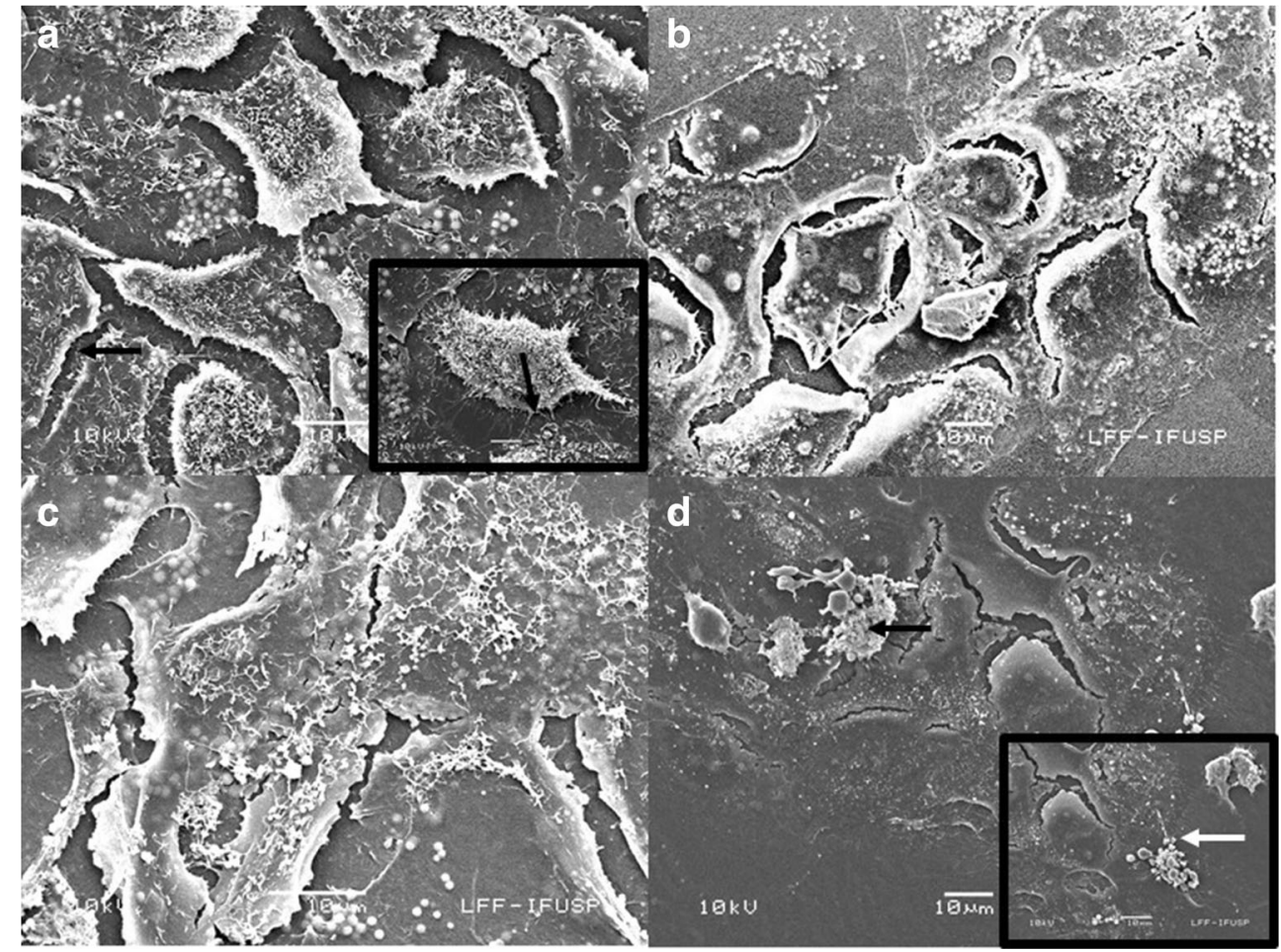


Fig. 3 Photomicrographs of T24 cells were obtained using scanning electron microscopy: (a) untreated cells (control), (b) cells treated with cisplatin $(1.0 \mu \mathrm{mol} /$ L), cells treated with gemcitabine $(1.56 \mu \mathrm{mol} / \mathrm{L})$, and $(\mathbf{d})$ cells treated with cisplatin + gemcitabine $(1.0 \mu \mathrm{mol} / \mathrm{L}$ cisplatin $+1.56 \mu \mathrm{mol} / \mathrm{L}$ gemcitabine). Black arrows indicate microfilaments, and white arrows indicate irregular morphology. Scale bar: $50 \mu \mathrm{m}$. These experiments were performed in triplicate

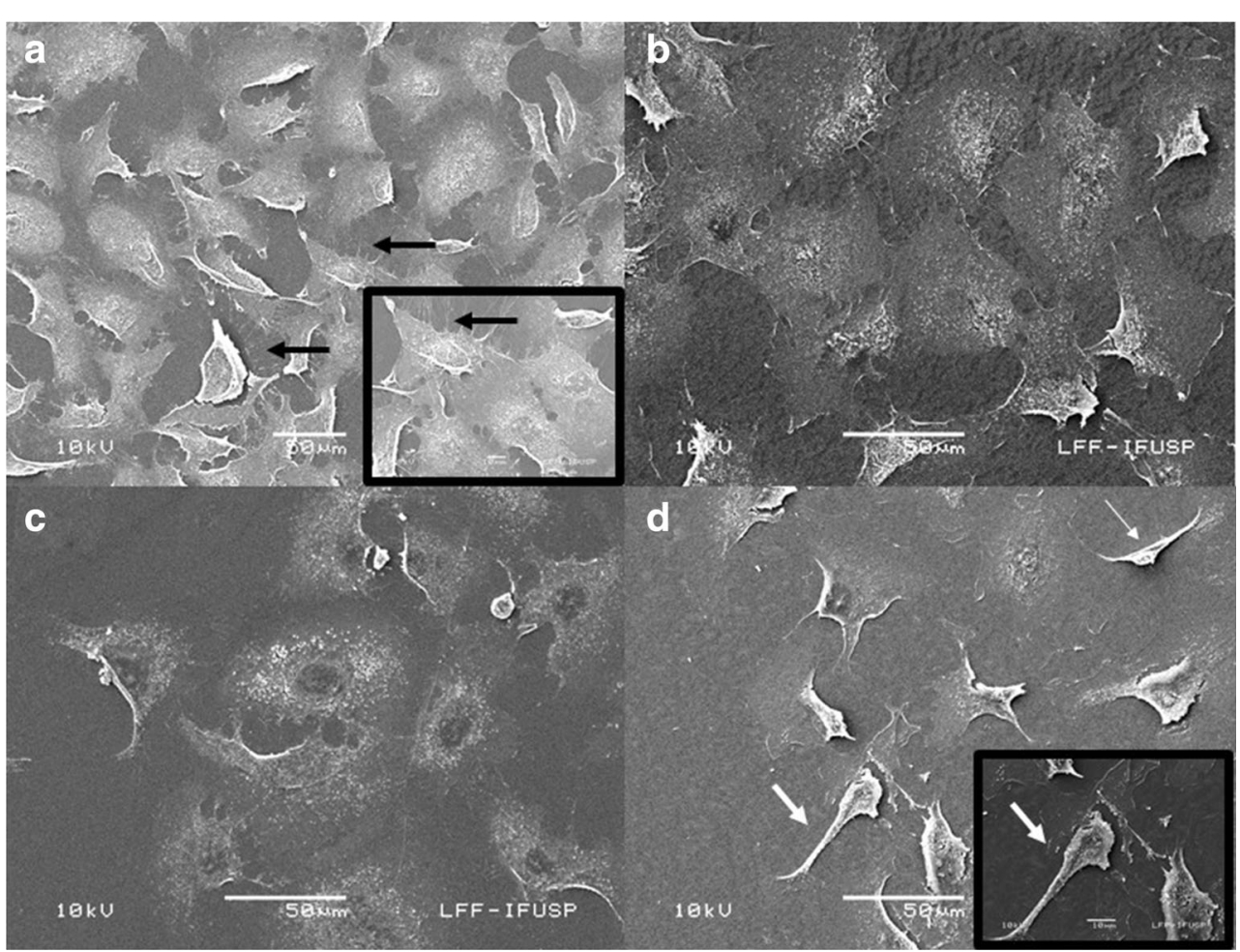

for $6.25 \mu \mathrm{mol} / \mathrm{L}$ ) after treatment with gemcitabine. However, the highest rates of apoptosis were observed at 24 and $48 \mathrm{~h}$ after cells were simultaneously treated with gemcitabine + cisplatin at various combinations that were tested. With regard for necrotic cells, an increase in the percentage of necrotic cells was observed immediately $(3.0 \%$ for $1.0 \mu \mathrm{mol} / \mathrm{L}$ and $3.80 \%$ for $2.5 \mu \mathrm{mol} / \mathrm{L})$ and at $48 \mathrm{~h}(5.0 \%$ for $2.5 \mu \mathrm{mol} / \mathrm{L}$ and $3.60 \%$ for $5.0 \mu \mathrm{mol} / \mathrm{L}$ ) after treatment with cisplatin. For gemcitabine, an increase in the percentage of necrotic cells was observed at $48 \mathrm{~h}$ after treatment $(3.80 \%$ for $1.56 \mu \mathrm{mol} / \mathrm{L}$, $5.20 \%$ for $3.125 \mu \mathrm{mol} / \mathrm{L}$ and $5.0 \%$ for $6.25 \mu \mathrm{mol} / \mathrm{L})$. When cells were simultaneously treated with both drugs, an increase in the percentage of necrotic cells was observed at $24 \mathrm{~h}$ after treatment with all tested concentrations (Table 2 and Fig. 7).

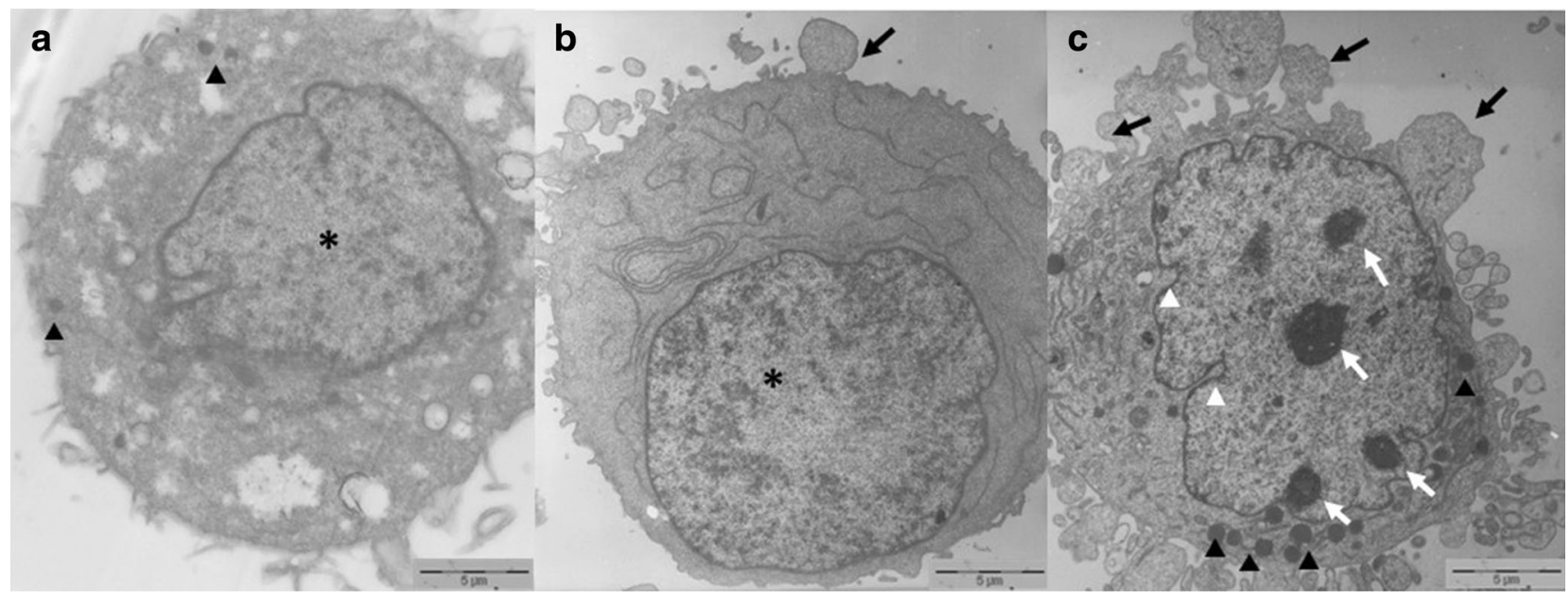

Fig. 4 Photomicrographs of RT3 (a), 5637 (b) and T24 (c) cells were obtained using transmission electron microscopy. * Decondensed chromatin; cytoplasmic prolongations and nucleolus are indicated by black and white arrows, respectively. White arrowheads indicate nuclear chamfers, while black arrowheads indicate electron-dense granules. Scale bar: $10 \mu \mathrm{m}$. These experiments were performed in triplicate 
Fig. 5 Photomicrographs of the following groups of T24 cells were obtained using transmission electron microscopy: (a) untreated cells (control), (b) cisplatin-treated cells $(1.0 \mu \mathrm{mol} /$ L), (c) gemcitabine-treated cells $(1.56 \mu \mathrm{mol} / \mathrm{L})$, and (d) cells treated with cisplatin + gemcitabine $(1.0 \mu \mathrm{mol} / \mathrm{L}$ cisplatin $+1.56 \mu \mathrm{mol} / \mathrm{L}$ gemcitabine). Black arrows indicate smaller nuclei and a larger number and extended size of nuclear chamfers in comparison to the untreated cells. Scale bar: $5 \mu \mathrm{m}$. These experiments were performed in triplicate

Fig. 6 Photomicrographs of the following groups of RT4 and 5637 cells were obtained using transmission electron microscopy: (a) untreated RT4 cells (control), (b) RT4 cells treated with cisplatin + gemcitabine $(1.0 \mu \mathrm{mol} / \mathrm{L}$ cisplatin $+1.56 \mu \mathrm{mol} / \mathrm{L}$ gemcitabine), (c) untreated 5637 cells (control) and (d) 5637 cells treated with cisplatin + gemcitabine $(1.0 \mu \mathrm{mol} / \mathrm{L}$ cisplatin $+1.56 \mu \mathrm{mol} / \mathrm{L}$ gemcitabine). Black arrows indicate smaller nuclei and a larger number and extended size of nuclear chamfers in comparison to the untreated cells. Scale bar: $5 \mu \mathrm{m}$. These experiments were performed in triplicate
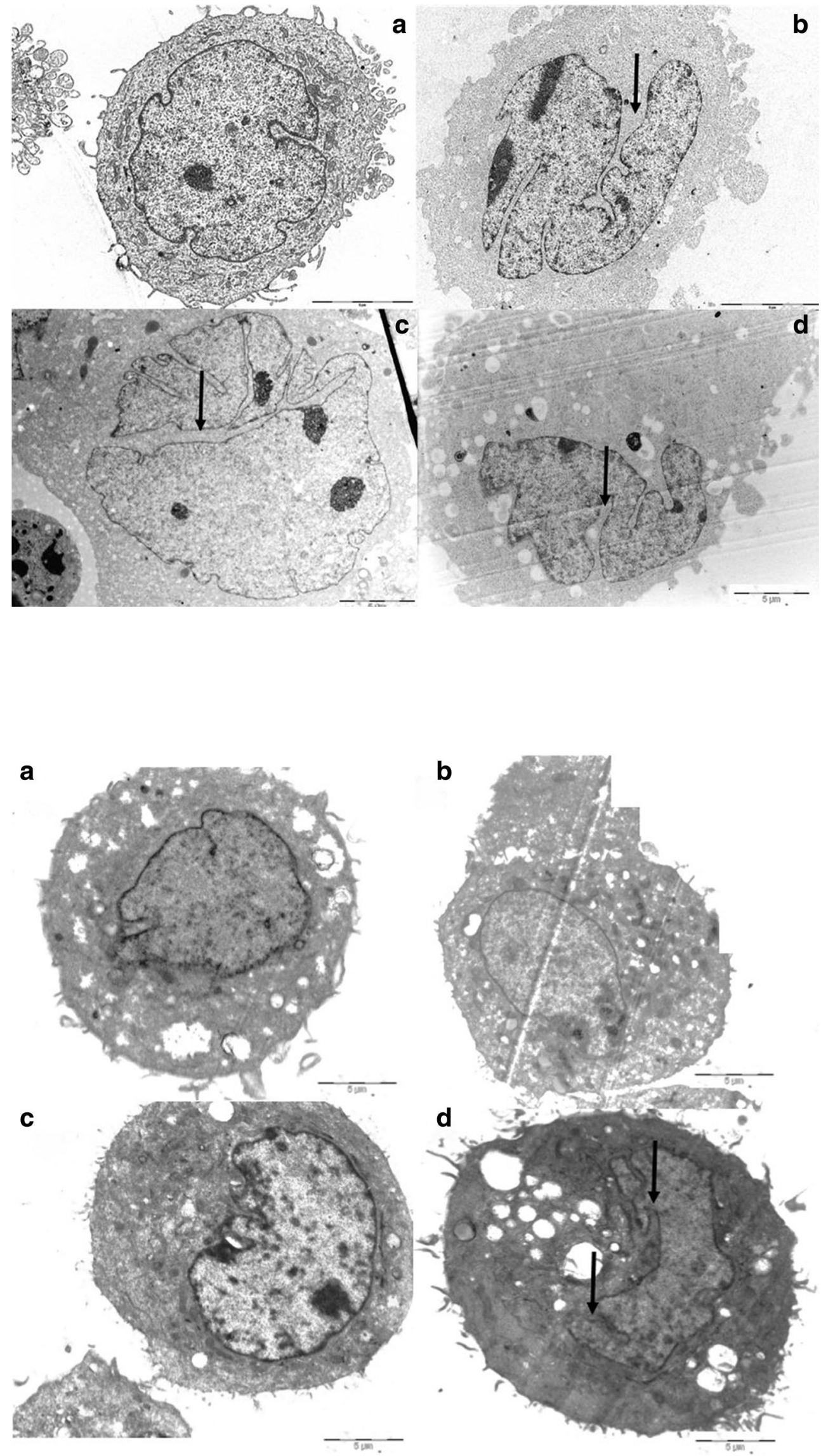
Table 1 The frequency (\%) of apoptotic and necrotic 5637 cells after 0,4 and $48 \mathrm{~h}$ of treatment with cisplatin and/or gemcitabine

\begin{tabular}{|c|c|c|c|c|c|c|c|}
\hline \multirow[t]{2}{*}{ Drug } & \multirow[t]{2}{*}{ Concentration } & \multicolumn{3}{|c|}{ Apoptotic cells } & \multicolumn{3}{|c|}{ Necrotic cells } \\
\hline & & $0 \mathrm{~h}$ & $24 \mathrm{~h}$ & $48 \mathrm{~h}$ & $0 \mathrm{~h}$ & $24 \mathrm{~h}$ & $48 \mathrm{~h}$ \\
\hline \multirow[t]{5}{*}{ Cisplatin $(\mu \mathrm{mol} / \mathrm{L})$} & Control & 0.92 & 0.86 & 0.66 & 1.26 & 1.26 & $2.12^{\#}$ \\
\hline & 0.5 & 1.40 & $2.06^{*}$ & 1.40 & $2.40 *$ & $1.26^{\#}$ & $0^{* \#}$ \\
\hline & 1.0 & 1.66 & 1.46 & 3.92 *\# & $2.52 *$ & $1.40^{\#}$ & 3.26 \\
\hline & 2.5 & $4.32 *$ & $5.32 *$ & $3.66^{*}$ & $3.00 *$ & $1.52^{\#}$ & 0.72 *\# \\
\hline & 5.0 & $5.40 *$ & $13.92 * \#$ & $15.86^{* \#}$ & $5.66^{*}$ & $0.2^{* \#}$ & $0.26^{* \#}$ \\
\hline \multirow{5}{*}{ Gemcitabine $(\mu \mathrm{mol} / \mathrm{L})$} & Control & 0.92 & 0.86 & 0.66 & 1.26 & 1.26 & 2.12 \\
\hline & 0.78 & 1.12 & 1.52 & $1.72 *$ & $2.32 *$ & $1.26^{\#}$ & $1.20^{\#}$ \\
\hline & 1.56 & $3.72 *$ & $2.26^{* \#}$ & $8.32{ }^{* \#}$ & $2.26 *$ & 0 & 0.20 *\# \\
\hline & 3.125 & $7.32 *$ & $2.80^{* \#}$ & $9.00 *$ & 1.92 & 1.66 & $0.80^{* \#}$ \\
\hline & 6.25 & $9.40 *$ & $6.12 * \#$ & $16.6^{* \#}$ & 1.46 & 1.26 & 0.26 *\# \\
\hline \multirow[t]{5}{*}{ Cisplatin + Gemcitabine $(\mu \mathrm{mol} / \mathrm{L})$} & Control & 0.92 & 0.86 & 0.66 & 1.32 & 1.26 & 2.12 \\
\hline & $0.5+0.78$ & 1.00 & $2.72 * \#$ & $6.92{ }^{* \#}$ & $3.52 *$ & $5.66^{* \#}$ & $0.06^{* \#}$ \\
\hline & $0.5+1.56$ & $7.66 *$ & $6.46^{*}$ & $8.80 *$ & $6.92 *$ & $11.06^{* \#}$ & 3.32 *\# \\
\hline & $1.0+0.78$ & $2.86^{*}$ & $3.66^{*}$ & $6.66^{* \#}$ & $7.40 *$ & $9.66^{* \#}$ & 3.46 *\# \\
\hline & $1.0+1.56$ & $5.26 *$ & $12.32 * \#$ & $7.86^{* \#}$ & $7.52 *$ & $11.66^{* \#}$ & $19.8^{* \#}$ \\
\hline
\end{tabular}

The data are expressed as the mean \pm standard deviation from triplicate experiments

$* p<0.05$ compared to the respective control in the same column

$\# p<0.05$ compared to the respective $0 \mathrm{~h}$ cell sample (same row)

\section{PCR Arrays}

When compared to the controls, $7 / 84(8.3 \%)$ and $19 / 84$ $(22.6 \%)$ of the evaluated genes were differentially expressed (fold change $\geq 2$ ) in 5637 (Fig. 8a and Table 3) and T24 cells (Fig. $8 \mathrm{~b}$ and Table 4 ) after the cells were simultaneously treated with gemcitabine and cisplatin. $C D K N 2 B, G A D D 45 A$ and SERTAD1 were overexpressed in both cell lines after combined treatment.

\section{Discussion}

Determining the relationships between gene expression profiles and tumor sensitivity to antineoplastic drugs is fundamentally important for developing effective therapeutic approaches [15]. Therefore, this study was performed to evaluate the effect of cisplatin and gemcitabine activity on cell cycle-related genes in two bladder urothelial carcinoma cell lines that possess a mutated TP53 gene. Before we analyzed the transcriptome, the effects of gemcitabine and cisplatin on cell morphology were assessed. The morphological differences that were observed between the three cell lines indicate that T24 cells display increased metabolic activity, potentially because they originated from a higher degree tumor (grade 3). Previously, Vaezy and Zderic [16] suggested that the degree of metabolic activity in brain tumors may be correlated with the tumor's degree of malignance. Moreover, Rajcevic et al. [17] suggested that the general cellular metabolism of glioblastomas is more active in angiogenic than non-angiogenic phenotype glioblastomas.
Table 2 Frequency (\%) of apoptotic and necrotic T24 cells after 0,24 and $48 \mathrm{~h}$ of treatment with cisplatin and/or gemcitabine

\begin{tabular}{|c|c|c|c|c|c|c|c|}
\hline \multirow[t]{2}{*}{ Drug } & \multirow[t]{2}{*}{ Concentration } & \multicolumn{3}{|c|}{ Apoptotic cells } & \multicolumn{3}{|c|}{ Necrotic cells } \\
\hline & & $0 \mathrm{~h}$ & $24 \mathrm{~h}$ & $48 \mathrm{~h}$ & $0 \mathrm{~h}$ & $24 \mathrm{~h}$ & $48 \mathrm{~h}$ \\
\hline \multirow[t]{5}{*}{ Cisplatin $(\mu \mathrm{mol} / \mathrm{L})$} & Control & 3.40 & $1.60^{\#}$ & $0.60^{\#}$ & 1.40 & 1.80 & 2.00 \\
\hline & 0,5 & 3.00 & 2.40 & $1.40^{\#}$ & 2.00 & 1.00 & 2.20 \\
\hline & 1.0 & 3.40 & 2.40 & $1.60^{\#}$ & $3.00 *$ & 2.40 & $1.40^{\#}$ \\
\hline & 2.5 & 2.40 & 2.00 & 1.00 & $3.80^{*}$ & $1.60^{\#}$ & $5.00^{* \#}$ \\
\hline & 5.0 & 4.60 & $2.20^{\#}$ & 3.20 & 1.80 & 5.80 *\# & 3.60 *\# \\
\hline \multirow[t]{5}{*}{ Gemcitabine $(\mu \mathrm{mol} / \mathrm{L})$} & Control & 1.80 & 2.00 & 1.60 & 2.60 & 3.20 & 1.80 \\
\hline & 0.78 & 0.80 & $2.20^{\#}$ & $1.80^{\#}$ & 2.20 & 1.40 & 3.00 \\
\hline & 1.56 & 0.80 & $2.80^{\#}$ & $1.80^{\#}$ & 3.80 & 2.80 & $3.80 *$ \\
\hline & 3.125 & 1.20 & 3.20 *\# & $2.60^{\#}$ & 0.60 & 0.20 & 5.20 *\# \\
\hline & 6.25 & 1.40 & $4.00 * \#$ & 3.60 *\# & 0.20 & 1.60 & 5.00 *\# \\
\hline \multirow[t]{5}{*}{ Cisplatin + Gemcitabine $(\mu \mathrm{mol} / \mathrm{L})$} & Control & $\begin{array}{l}1.40 \\
1.00\end{array}$ & 1.80 & 1.60 & 3.00 & $1.00^{\#}$ & 3.00 \\
\hline & $0.5+0.78$ & 1.40 & $4.00^{* \#}$ & 2.40 & 1.80 & $2.80^{*}$ & $3.60^{\#}$ \\
\hline & $0.5+1.56$ & 1.60 & 4.60 *\# & 4.20 *\# & 3.00 & $3.20 *$ & 3.00 \\
\hline & $1.0+0.78$ & 1.00 & 5.80 *\# & 3.60 *\# & 2.60 & $3.80^{*}$ & 2.80 \\
\hline & $1.0+1.56$ & 1.60 & $5.80^{* \#}$ & 5.60 *\# & 2.60 & $3.20 *$ & 3.20 \\
\hline
\end{tabular}

$* \mathrm{p}<0.05$ compared to the respective control in the same column

$\# \mathrm{p}<0.05$ compared to the respective $0 \mathrm{~h}$ cell sample (same row)

The data are expressed as the mean \pm standard deviation from triplicate experiments 
Fig. 7 The morphology of 5637 (a) and T24 (b) cells at $72 \mathrm{~h}$ after treatment with cisplatin + gemcitabine was evaluated using Hoechst 33,342, propidium iodide and fluorescein diacetate Red arrows: intact nuclei, blue arrows: apoptotic cells, green arrows: necrotic cells (1000 X). These experiments were performed in triplicate
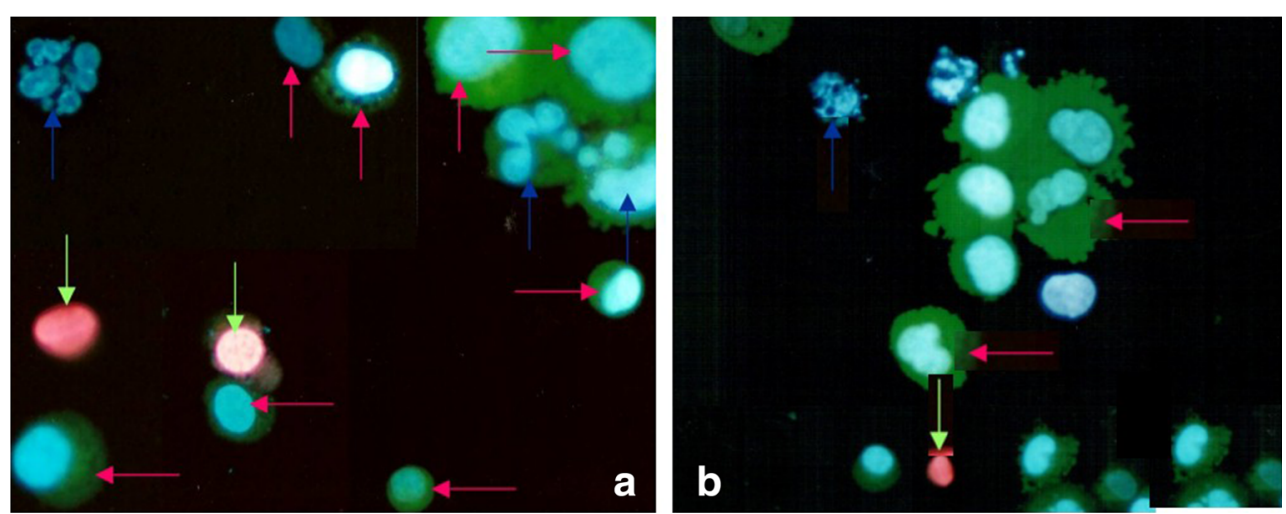

Scanning and transmission microscopy also revealed that morphological alterations (e.g., in the number of microfilaments and organelles, irregular contours, and the size of the nucleus) occurred after treatment. We suspect that the changes that were detected in cell shape and microvilli numbers resulted from impaired actin cytoskeletal polymerization and because there was a lower amount of contact between the cells themselves and between the cells and the extracellular matrix. This may be because these chemotherapeutic agents were purposefully designed to target cell membranes and the cytoskeleton, to induce cytotoxicity and to alter cytoadherence [18]. The actin network is a complex and important structural and functional system that provides the basic infrastructure that maintains cell morphology, adhesion, motility, exocytosis, endocytosis and cell division. Actin polymerization and remodeling play pivotal roles in regulating the morphology and phenotype of a malignant cell. Moreover, these actin filaments play important roles in mitosis and cell signaling [9]. Thus, alteration or decrease in cellular microfilaments could have compromised cellular viability. Additionally, the observed decreases in the size of the nucleus and the number of organelles might indicate a reduction in cellular metabolism. These events could contribute to or be a repercussion of cell cycle arrest or the early stages of cell death.

Scattered cells were also detected after cells were treated with cisplatin and gemcitabine, and these findings confirm that this drug combination exerts an antiproliferative effect, probably by stimulating apoptosis and necrosis, which were observed in the fluorescent apoptosis assay. Recently, Wang et al. [19] demonstrated that TP53 stimulates a wide network of signals that act
Fig. 8 Heat map showing the gene expression profile of the 5637 (a) and T24 (b) human bladder transitional carcinoma cell lines after the cells were simultaneously treated with gemcitabine + cisplatin $(1.0 \mu \mathrm{mol} / \mathrm{L}+1.56 \mu \mathrm{mol} / \mathrm{L}$ respectively). The data from three independent cultures are shown. Red, green and black spots indicate upregulated, downregulated and nonmodulated genes, respectively (fold change $\geq 2$ ) a ำ जิ जิ

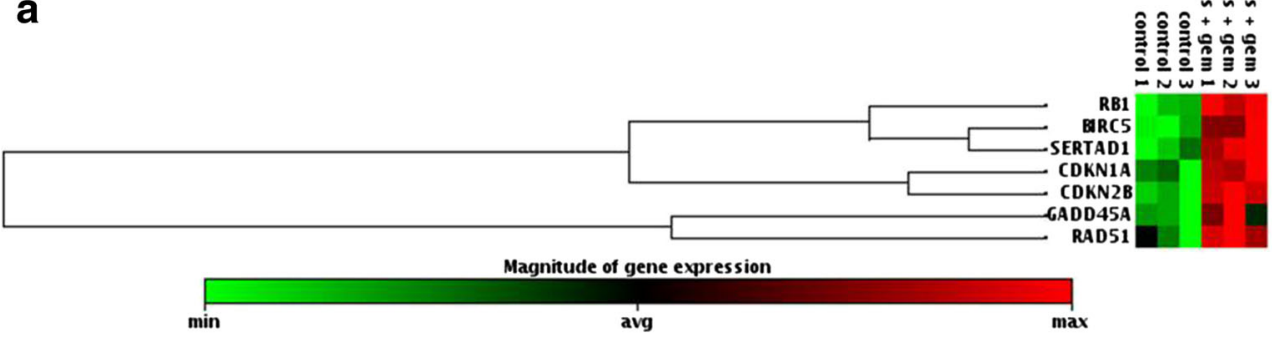

b ลิ ลิ जิ

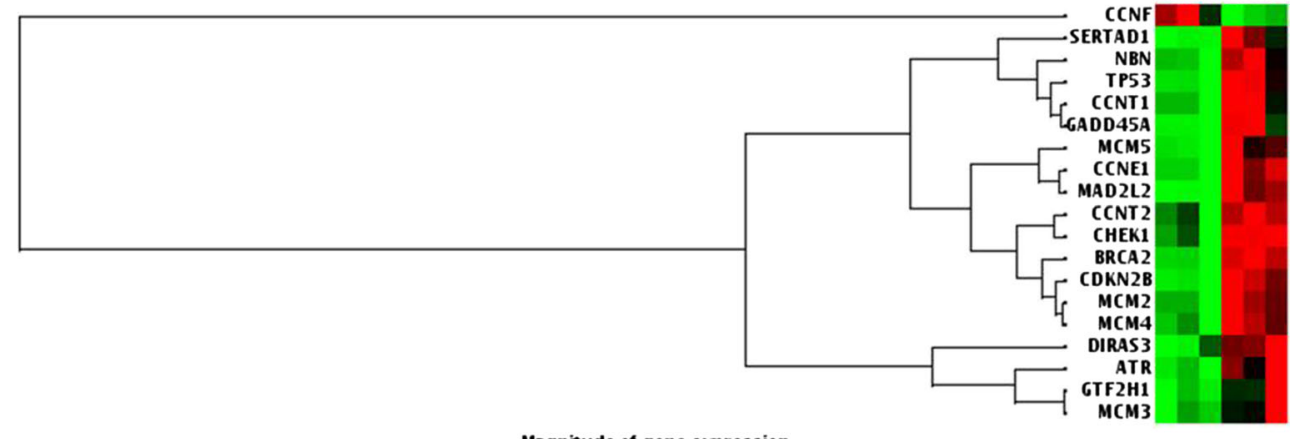

Magnitude of gene expression

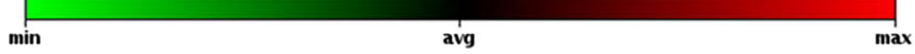


Table 3 Significantly $(p \leq 0.05$; fold change $\geq 2.0$ ) modulated genes in 5637 cells after simultaneous treatment with cisplatin $(1.0 \mu \mathrm{mol} / \mathrm{L})$ and gemcitabine $(1.56 \mu \mathrm{mol} / \mathrm{L})$

\begin{tabular}{lllll}
\hline Symbol & Ref seq & Complete name & Change & $P$ value \\
\hline RB1 & NM_000321 & Retinoblastoma 1 & 2.13 & 0.011134 \\
BIRC5 & NM_001168 & Baculoviral IAP repeat containing 5 & 2.45 & 0.001257 \\
SERTAD1 & NM_013376 & SERTA domain containing 1 & 2.07 & 0.001242 \\
CDKN1A & NM_000389 & Cyclin-dependent kinase inhibitor 1A (p21. Cip1) & 7.90 & 0.002439 \\
CDKN2B & NM_004936 & Cyclin-dependent kinase inhibitor 2B (p15. inhibits CDK4) & 3.07 & 0.000136 \\
GADD45A & NM_001924 & Growth arrest and DNA-damage inducible alpha & 5.25 & 0.027393 \\
RAD51 & RAD51 & RAD51 homolog (S. cerevisiae) & 2.13 & 0.011134 \\
\hline
\end{tabular}

through two major apoptotic pathways: 1) the death receptor pathway, which triggers the activation of a caspase cascade, and 2) a mitochondrial pathway that shifts the balance in the expression of $B c l-2$ family members towards pro-apoptotic members, thereby promoting the formation of the apoptosome and, consequently, caspase-mediated apoptosis. Nevertheless, Wang et al. [20] previously reported that cancer cells lacking a functional TP53 were also killed by cisplatin via a TP53-independent mechanism that was similar to replicative senescence. Furthermore, there is evidence showing that genes other than TP53 also participate in regulating DNA repair and apoptotic mechanisms [21]. Similarly to our previous findings [12], Fencher et al. [22] also observed that apoptosis occurred independently of TP53 status in bladder urothelial carcinoma cell lines.

To gain a better understanding of the mechanisms underlying the activities of cisplatin and gemcitabine, we evaluated their effects on gene expression profiles. The data showed that $C D K N 2 B, G A D D 45 A$ and SERTAD1 were upregulated. According to the gene ontology (GO) analysis, these genes are primarily involved in negatively regulating the cell cycle and cell cycle arrest (CDKN2B and GADD45A), G1/S transition $(C D K N 2 B)$, DNA repair and apoptosis $(G A D D 45 A)$ and the regulation of transcription (SERTAD1). Additionally, some of these genes are targets of cancer treatments. While
$G A D D 45 A$ expression has been associated with the efficiency of 5-aza-CdR to treat different pancreatic cancer cell lines [23], $C D K N 2 B$, a cyclin-dependent kinase inhibitor, is a tumor suppressor gene that inhibits cell cycle progression [24]. Interestingly, SERTAD1, which is known to inhibit $\mathrm{p} 16^{\mathrm{INK} 4 \mathrm{a}}$ activity [25], is overexpressed in several cancers and associated with oncogenic potential [26]. However, L'Espérance et al. [27] have also shown that SERTAD1 is upregulated in ovarian cancer cells after treatment with Topotecan.

It is important to emphasize that differences in gene expression (fold change $\geq 2$ ) were detected between the two cell lines. Four genes were significantly modulated in only the 5637 cells, while 16 genes were significantly modulated in only the T24 cells. In a previous study we have also suggested that MRE11A (which is involved in the response to a DNA damage stimulus and the cellular response to stress) and SKP2 (involved in the negative regulation of the cell cycle) downregulation seemed be responsible for the synergistic therapeutic effects of cisplatin and gemcitabine in wild type TP53 cell line [28]. This discrepancy in the expression profile intensities of these genes supports the notion that complex mechanisms are involved in carcinogenesis. In conclusion, gemcitabine and cisplatin caused morphological alterations that are supportive of their antiproliferative potential and upregulated
Table 4 Significantly $(p \leq 0.05$; fold change $\geq 2.0$ ) modulated genes in T24 cells after simultaneous treatment with cisplatin $(1.0 \mu \mathrm{mol} / \mathrm{L})$ and gemcitabine $(1.56 \mu \mathrm{mol} / \mathrm{L})$

\begin{tabular}{lllll}
\hline Symbol & Ref seq & Complete name & Change & $P$ value \\
\hline CCNF & NM_001761 & Cyclin F & -2.12 & 0.020050 \\
SERTAD1 & NM_013376 & SERTA domain containing 1 & 4.31 & 0.012048 \\
NBN & NM_002485 & Nibrin & 2.58 & 0.008211 \\
$T P 53$ & NM_000546 & Tumor protein p53 & 7.00 & 0.005334 \\
CCNT1 & NM_001240 & Cyclin T1 & 2.73 & 0.016640 \\
GADD45A & NM_001924 & Growth arrest and DNA-damage inducible. Alpha & 6.32 & 0.019802 \\
$M C M 5$ & NM_006739 & Minichromosome maintenance complex component 5 & 2.43 & 0.005926 \\
CCNE1 & NM_001238 & Cyclin E1 & 3.25 & 0.000576 \\
$M A D 2 L 2$ & NM_006341 & MAD2 mitotic arrest deficient-like 2 (yeast) & 2.17 & 0.000562 \\
CCNT2 & NM_001241 & Cyclin T2 & 3.12 & 0.004013 \\
CHEK 1 & NM_001274 & CHK1 checkpoint homolog (S. pombe) & 2.02 & 0.001228 \\
BRCA2 & NM_000059 & Breast cancer 2, early onset & 4.26 & 0.000044 \\
CDKN2B & CDKN2B & Cyclin-dependent kinase inhibitor 2B (p15 inhibits CDK4) & 4.23 & 0.000459 \\
$M C M 2$ & NM_004526 & Minichromosome maintenance complex component 2 & 2.28 & 0.001961 \\
$M C M 4$ & NM_005914 & Minichromosome maintenance complex component 4 & 2.37 & 0.002495 \\
DIRAS3 & NM_004675 & DIRAS family. GTP-binding RAS-like 3 & 2.01 & 0.006569 \\
ATR & NM_001184 & Ataxia telangiectasia and Rad3 related & 2.24 & 0.008219 \\
GTF2H1 & NM_005316 & General transcription factor IIH. polypeptide & 2.36 & 0.047905 \\
$M C M 3$ & NM_002388 & Minichromosome maintenance complex component 3 & 2.09 & 0.041394 \\
\hline
\end{tabular}


GADD45A, CDKN2B and SERTAD1. These effects were independent of the type of TP53 mutation in the cells and the tumor grade. The identification of gemcitabine- and cisplatinresponsive genes provides insight into their anti-cancer mechanisms and shows that these genetic profiles can be used in a clinical setting to predict responses to chemotherapies.

Author Contributions GNS contributed to the experimental design and the interpretation of data, performed the scanning and transmission electron microscopy and PCR array experiments, and wrote the manuscript. LTF performed scanning electron microscopy. MCBS contributed to the interpretation of the data and critically read the manuscript. DMFS contributed to the experimental design, the interpretation of data, and the critical reading of the manuscript.

\section{Compliance with Ethical Standards}

Conflict of Interest The authors declare that they have no competing interests.

Funding This study was supported by the Fundação de Amparo à Pesquisa do Estado de São Paulo (FAPESP - 2008/09147-6), Fundação de Amparo à Pesquisa do Estado de Minas Gerais (CBB - APQ-0149714) and the Conselho Nacional de Desenvolvimento Científico e Tecnológico (CNPq).

\section{References}

1. von der Maase H, Sengelov L, Roberts JT, Ricci S, Dogliotti L, Oliver T et al (2005) Long-term survival results of a randomized trial comparing gemcitabine plus cisplatin, with methotrexate, vinblastine, doxorubicin, plus cisplatin in patients with bladder cancer. J Clin Oncol 23:4602-4608. doi:10.1200/JCO.2005.07.757

2. Yuh BE, Ruel N, Wilson TG, Vogelzang N, Pal SK (2013) Pooled analysis of clinical outcomes with neoadjuvant cisplatin and gemcitabine chemotherapy for muscle invasive bladder cancer. J Urol 189:1682-1686. doi:10.1016/j.juro.2012.10.120

3. Wang D, Lippard SJ (2005) Cellular processing of platinum anticancer drugs. Nat rev Drug Discov 4:307-319. doi:10.1038/nrd1691

4. Toschi L, Finocchiaro G, Bartolini S, Gioia V, Cappuzzo F (2005) Role of gemcitabine in câncer therapy. Future Oncol 1:7-17. doi: 10.1517/14796694.1.1.7

5. Coppée J-Y (2008) Do DNA microarrays have their future behind them? Microbes Infect 10:1067-1071. doi:10.1016/j.micinf.2008. 07.003

6. Rentsch CA, Stenner F, Ruiz C, Bubendorf L (2015) Three genes to predict response to chemotherapy for bladder cancer: individualised cancer care at the doorstep. Eur Urol 68:968-969. doi:10.1016/j. eururo.2015.07.050

7. Da Silva GN, de Camargo EA, Salvadori DM (2012) Toxicogenomic activity of gemcitabine in two TP53-mutated bladder cancer cell lines: special focus on cell cycle-related genes. Mol Biol rep 39(12):10373-10382. doi:10.1007/s11033-012-1916-1
8. Sávio AL, da Silva GN, Salvadori DM (2015) Inhibition of bladder cancer cell proliferation by allyl isothiocyanate (mustard essential oil). Mutat res 771:29-35. doi:10.1016/j.mrfmmm.2014.11.004

9. Gonçalves EM, Ventura CA, Yano T, Rodrigues Macedo ML, Genari SC (2006) Morphological and growth alterations in Vero cells transformed by cisplatin. Cell Biol Int 30:485-494. doi:10. 1016/j.cellbi.2005.12.007

10. Chen NG, Chen KT, Lu CC, Lan YH, Lai CH, Chung YT et al (2010) Allyl isothiocyanate triggers G2/M phase arrest and apoptosis in human brain malignant glioma GBM 8401 cells through a mitochondria-dependent pathway. Oncol rep 24:449-455

11. Nishiyama H, Watanabe J, Ogawa O (2008) p53 and chemosensitivity in bladder cancer. Int J Clin Oncol 13:282-286. doi:10.1007/s10147-008-0815-x

12. Da Silva GN, de Castro Marcondes JP, de Camargo EA, da Silva Passos Júnior GA, Sakamoto-Hojo ET, Salvadori DM (2010) Cell cycle arrest and apoptosis in TP53 subtypes of bladder carcinoma cell lines treated with cisplatin and gemcitabine. Exp Biol med (Maywood) 235:814-824. doi:10.1258/ebm.2010.009322

13. Camargo EA, da Silva GN, Gobette CP, Marcondes JP, Salvadori DM (2013) No relationship between the amount of DNA damage and the level of hMLH1 and RASSF1A gene expression in bladder cancer cells treated with cisplatin and gemcitabine. Asian Pac J Cancer Prev 4:5941-5948. doi:10.7314/APJCP.2013.14.10.5941

14. Rovida AFS, Endo KM, POlli AD, Bulla LMC, Scudeler EL, Abreu JAS et al (2015) Use of neem (Azadirachta indica a Juss) oil in the control of Musca domestica L.(Diptera:Muscidae) in poultry breeding farms. J World's Poult res 5:73-83

15. Liu Y, Kwiatkowski DJ (2015) Combined CDKN1A/TP53 mutation in bladder cancer is a therapeutic target. Mol Cancer Ther 14: 174-182. doi:10.1158/1535-7163.MCT-14-0622-T

16. Vaezy S, Zderic V (2009) Image-guided therapy systems. Artech House INC, Washington DC

17. Rajcevic U, Petersen K, Knol JC, Loos M, Bougnaud S, Klychnikov O et al (2009) iTRAQ-based proteomics profiling reveals increased metabolic activity and cellular cross-talk in angiogenic compared with invasive glioblastoma phenotype. Mol Cell Proteomics 8:2595-2512. doi:10.1074/mcp.M900124-MCP200

18. Suresh S (2007) Biomechanics and biophysics of cancer cells. Acta Biomater 3:413-438. doi:10.1016/j.actbio.2007.04.002

19. Wang X, Simpson ER, Brown KA (2015) P53: protection against tumor growth beyond effects on cell cycle and apoptosis. Cancer res 75:5001-5007. doi:10.1158/0008-5472.CAN-15-0563

20. Wang X, Wong SC, Pan J, Tsao SW, Fung KH, Kwong DL et al (1998) Evidence of cisplatin-induced senescent-like growth arrest in nasopharyngeal carcinoma cells. Cancer res 58:5019-5022

21. Lu TX, Young KH, Xu W, Li JY (2016) TP53 dysfunction in diffuse large B-cell lymphoma. Crit rev Oncol Hematol 97:47-55. doi:10.1016/j.critrevonc.2015.08.006

22. Fechner G, Perabo FG, Schmidt DH, Haase L, Ludwig E, Schueller $\mathrm{H}$ et al (2003) Preclinical evaluation of a radiosensitizing effect of gemcitabine in p53 mutant and p53 wild type bladder cancer cells. Urology 61:468-473. doi:10.1016/S0090-4295(02)02156-8

23. Missiaglia E, Donadelli M, Palmieri M, Crnogorac-Jurcevic T, Scarpa A, Lemoine NR (2005) Growth delay of human pancreatic cancer cells by methylase inhibitor 5-aza-2. Oncogene 24:199-211. doi:10.1038/sj.onc.1208018 
24. Chim CS, Kwong YL (2006) Adverse prognostic impact of CDKN2B hyper-methylation in acute promyelocytic leukemia. Leuk Lymphoma 47:815-825. doi:10.1080/10428190500513827

25. Gupta S, Takhar PP, Degenkolbe R, Koh CH, Zimmermann H, Yang $\mathrm{CM}$ et al (2003) The human papillomavirus type 11 and 16 E6 proteins modulate the cell-cycle regulator and transcription cofactor TRIP-Br1. Virology 317:155-164. doi:10.1016/j.virol.2003.08.008

26. Darwish H, Cho JM, Loignon M, Alaoui-Jamali MA (2007) Overexpression of SERTAD3, a putative oncogene located within the $19 \mathrm{q} 13$ amplicon, induces E2F activity and promotes tumor growth. Oncogene 26:4319-4328. doi:10.1038/sj.onc.1210195
27. L'Espérance S, Bachvarova M, Tetu B, Mes-Masson AM, Bachvarov D (2008) Global gene expression analysis of early response to chemotherapy treatment in ovarian cancer spheroids. BMC Genomics 9:99. doi:10.1186/1471-2164-9-99

28. da Silva GN, de Camargo EA, Sávio AL, Salvadori DM (2014) MRE11A and SKP2 genes are associated with the increased cytotoxicity induced by the synergistic effects of cisplatin and gemcitabine in bladder cancer cells. Mol Biol rep 41:4613-4621. doi:10.1007/s11033-014-3332-1 